\title{
Fluidyne Heat Engine Construction and Performance ${ }^{1,2}$
}

\author{
Y. Shahabasi ${ }^{3}$
}

\begin{abstract}
Strictly speaking, all forms of energy are derived from the sun. However, our most common forms of energy, fossil-fuels, received their solar input eons ago and have changed their characteristics so that they are now in concentrated form. It is apparent that these stored concentrated energy forms are now being used at such a rapid rate that they will be depleted in the not-toodistant future. It would be useful to utilize the incoming solar energy directly.

The effective use of the sun's energy in agriculture by any economically possible means will help the farmers continue their work with no disruption because of the lack of concentrated form of energy.

The fluidyne heat engine utilizes solar energy to pump water. The simplicity, reliability, and low cost of this engine are of primary importance for the farmers in the part of the world whereas solar energy is abundant such as Puerto Rico.
\end{abstract}

\section{INTRODUCTION}

The world has become concerned about energy and alternative sources of power. In the past, the easy availability and low cost of fossil-fuels (gas, coal, and oil) have made these sources of energy the predominant ones. Thus research and development of other energy sources have been seriously curtailed. with fossil-fuels now becoming more difficult to obtain, even being exhausted in some cases and considerably more expensive, there is keen motivation to explore natural resources of energy, such as solar, wind, tide, and wave action $(1,2)$.

An engine that has the potential to operate on solar energy as well as on any other sources of low grade heat is the stirling engine, or the hot air cycle engine. Although this engine has been known since 1816, there is currently considerable renewed interest in it (3).

In any stirling cycle machine gas is transferred or displaced from a cold space to a hot space. The resulting increase in gas pressure can provide power if it acts upon a moving piston. The gas is then displaced back into the cold space decreasing its pressure, drawing the power piston back in position to repeat the sequence (4).

The concept (5) of the stirling engine, like many developments in science and engineering, arose at the interface between two different fields of investigation fluid-mechanics and thermodynamics. ${ }^{4}$

${ }^{1}$ Manuscript submitted to Editorial Board October 10, 1983.

${ }^{2}$ Data taken from the author's technical problem report required for the degree of Master of Science, Michigan State University, East Lansing, Michigan, March 1976.

${ }^{3}$ Assistant Professor, Agricultural Engineering Department, University of Puerto Rico, Mayagüez, P. R. The author is indebted to Dr. R. H. Wilkinson, Professor, Agricultural Engineering Department, Michigan State University, and to Dr. C. West, Physicist, Harwell Laboratory, England, for their guidance and many helpful suggestions.

${ }^{4}$ West Colin personal communications. 
The application of stirling principles has been studied previously, describing an engine with no moving parts, driven by stirling cycle, and capable of pumping water when supplied with a modest heat source (3, $5,6)$. This engine has been known as fluidyne pump and could be used for irrigational purposes in the areas of the world where solar energy is abundant. The fluidyne engine operates on the principle of the stirling engine where the "pistons" are columns of liquid.

Further investigation for the construction, performance, and application of a fluidyne pump has been suggested (6). Evaluation of this engine in terms of principle of work and feasibility to convert solar energy or any low grade heat to mechanical power prompted this study.

\section{MATERIALS AND METHODS}

\section{CONSTRUCTION OF ACTUAL FLUIDYNE PUMP}

In this study, an attempt was made to construct a pump so that the water motion and oscillation could be observed. The first pump was made with plastic materials (Plexiglas) with the exception of the cooling and heating tubes which were copper piping. Plexiglas tubing provided good visibility of motion of water in the pump.

The displacer itself consisted of two vertical copper pipes each about $30 \mathrm{~cm}$ long and $4.45 \mathrm{~cm}$ I.D., and a horizontal Plexiglas tube $100 \mathrm{~cm}$ long, $12.5 \mathrm{~cm}$ I.D. (fig. 1).

The right hand limb of the displacer (right hand copper pipe) was surrounded by a cooling chamber made of Plexiglas (volume of $2.76 \mathrm{~L}$ ) and had two openings, the inlet and the outlet. On the left hand limb of the displacer was the heating part consisting of the copper tube wrapped with asbestos paper to insulate the heating coil. The heating coil had a resistance of $50 \mathrm{ohms}$.

The generator was a copper tube of $0.64 \mathrm{~cm}$ I.D. and $90 \mathrm{~cm}$ long, connecting the top part of the copper tubes by means of a valve (valve A). There was another valve (valve B) on the top of the left hand limb for filling the engine with water.

The output tube was made of a horizontal clear plastic tube and a vertical tube with two check valves (fig. 1).

The main advantage of having many parts of the pump made of plastic was visibility of the motion and the oscillation of water in the tubes. Coloring of water at different points was helpful for better visualizing water motion inside of the pump.

Melting of above plastic materials in the higher temperature ranges, particularly at the point where the hot limb was connected to the horizontal tube in the displacer section necessitated the construction of 


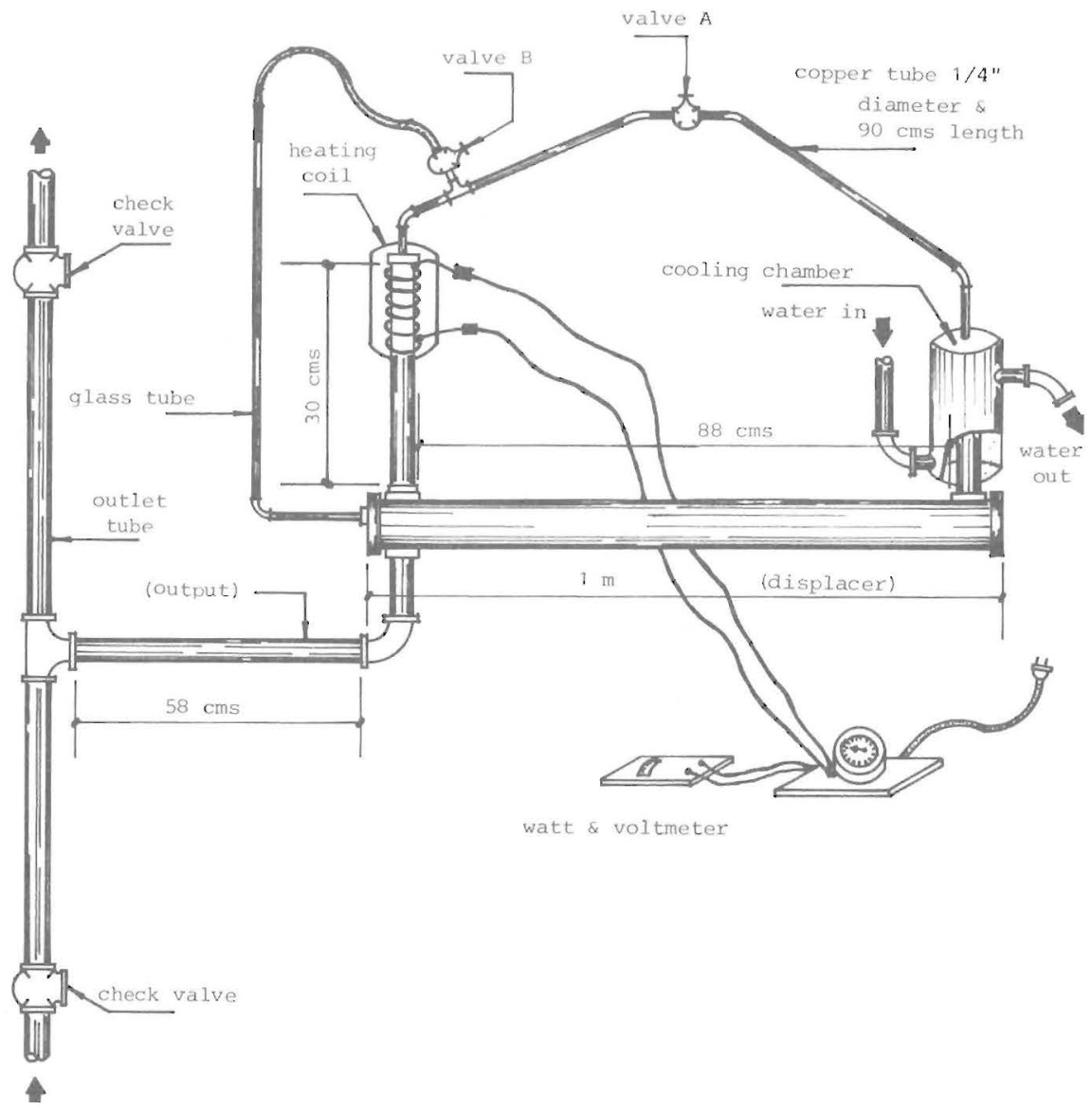

FIG. 1.-The schematic diagram of constructed Fluidyne engine.

a second pump with galvanized tubing. The second pump allowed for the possibility of applying higher temperatures (fig. 2).

\section{OPERATION OF THE FLUIDYNE PUMP}

For the laboratory tests, heat was provided by an electric resistance coil wrapped around the copper tube, producing the heat needed for operating the pump. This was necessary to test the pump for different levels of input heat. In practice, the heat can be generated by small flat plate collectors using water or air as circulating fluid.

The procedure of running the pump was as follows:

The engine was filled with water through valve $\mathrm{A}$ (fig. 2). Valve $\mathrm{C}$ was 
opened during filling period allowing both hot and cold limbs of the engine to be filled up to two-thirds of their height. Valves $\mathrm{A}$ and $\mathrm{C}$ were then closed trapping the remaining air on the top of the limbs. Before starting, the engine must be in a level position.

After the engine was filled with water, the heat was applied to the hot limb by the heating coil. The air above the water in the hot side began to expand, increasing the pressure in the system. The built-up pressure caused the water in the output tube to begin to move. This process continued for a period of time, according to how rapid the system was heated.

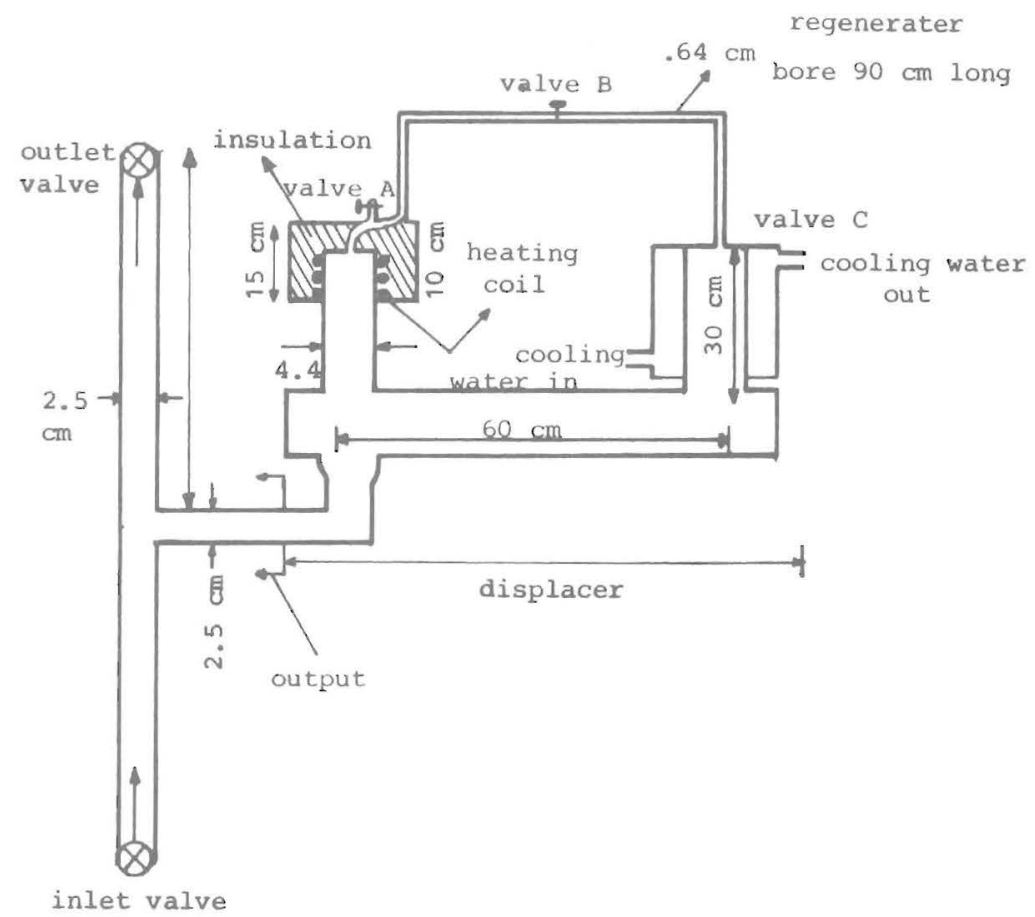

FIG. 2.-A schematic diagram of different parts of the constructed pump.

As the water in the output tube moved, it affected the water in the cold limb and the balance between the hot and cold limb was disturbed, thus beginning the oscillatory motion. The oscillation would increase with feedback as heating and cooling continued.

This process kept repeating itself and caused a strong oscillation in the engine. In practice, the cooling water for the fluidyne pump could be supplied by the discharge of the outlet valve. 
In the configuration described above the fluidyne is self-starting, as there is no static friction to overcome, but the efficiency is low.

A method of keeping the displacer liquid in oscillation is to "feed back" some of the output energy to the displacer fluid. In this system, the output tube is fed into the bottom of the displacer column, close to the hot side of the machine. As the water rushes in and out of the right hand end of the output tube, it drags some of the water in the displacer water moving back and forth.

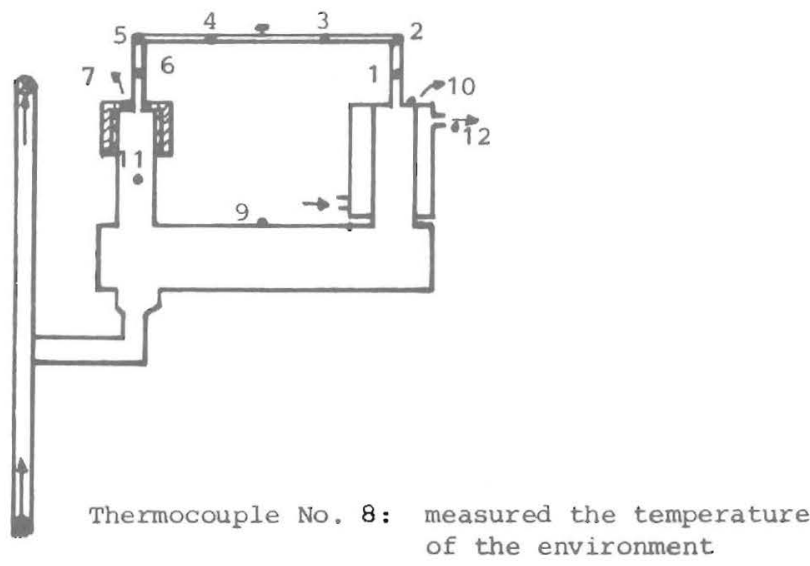

FIG. 3.-Thermocouple locations on the engine.

TABLE 1.-Variation of amplitude of oscillation due to different watts input

\begin{tabular}{ccccc}
\hline Power input & $\begin{array}{c}\text { Cooling } \\
\text { flow rate }\end{array}$ & $\begin{array}{c}\text { Cooling rate } \\
\text { calory of heat }\end{array}$ & $\begin{array}{c}\text { Amplitude of } \\
\text { oscillation }\end{array}$ & $\begin{array}{c}\text { Oscillation } \\
\text { time rate }\end{array}$ \\
\hline watts & $\mathrm{cm}^{3} /$ min & removed/min & $\mathrm{cm}$ & $\mathrm{s}$ \\
120 & 2400 & 40,800 & 9 & 1.5 \\
140 & 2400 & 40,800 & 20 & 1.5 \\
170 & 2400 & 40,800 & 35 & 1.5 \\
190 & 2400 & 40,800 & 36 & 1.5 \\
200 & 2400 & 40,800 & 38 & 1.5 \\
\hline
\end{tabular}

The steady source of heat can induce a sinusoidal motion in the water columns without the intervention of crank shaft or valves.

\section{RESULTS AND DISCUSSION}

The temperature of the circulating fluid (air, water) at 10 different points on the engine and at the point where the water exited from the cooling chamber, were monitored by thermocouples cemented at the 
respective locations (fig. 3). The thermocouples were connected to a Texas Multi Riter recorder. ${ }^{5}$

Heat input varied and cooling flow rate was held constant. The results are shown in table 1. Oscillation displacements are an indication of the potential output of the engine.

Table 2 shows temperature variation at different locations of the engine, from the time of starting the system (turning on the electricity) until the system began to oscillate and reached a steady state.

The duration from start up until the system began to oscillate was 29 minutes.

The height of the oscillation in this test as was measured by a floating stick inserted in the output tube, averaged between 20 to $30 \mathrm{~cm}$.

With the cooling rate held at $2.5 \mathrm{~L} / \mathrm{min}$ of water flow $(42,500 \mathrm{cal} / \mathrm{min})$ and the power input increased to 220 watts, there was not a very significant increase in output amplitude. Figure 4 shows different amplitudes of oscillation for different watts input with constant cooling rate of $2.4 \mathrm{~L} / \mathrm{min}$ of water.

The period of oscillation shown in table 1 for this engine was always 3 seconds. Changing the cooling flow rate and heat input, did not change the oscillation period significantly. This suggests that the sinusoidal function of oscillation is almost independent of the magnitude of input power (watts) and the cooling flow rate. An increase of the input power (heat) increases the amplitude of oscillation, but the period remains constant (fig. 4).

Following are the basic conclusions derived from the test:

1. There is a threshold temperature for operating the fluidyne engine leading to a threshold energy input.

2. The change in input power changes the amplitude of oscillation, but it has no significant effect on the oscillation frequency.

3. The constructed pump operated at water temperature less than $212^{\circ}$ $\mathrm{F}\left(160^{\circ}-170^{\circ} \mathrm{F}\right)$ in the hot limb and $70^{\circ} \mathrm{F}$ in the cold limb. This range of temperature could be obtained by solar energy or waste heat (low grade heat).

4. The pumping capacity of fluidyne increases with the power input and the relation between input and output power is not completely linear.

5. This pump can be very well used in Puerto Rico where there is enough sunshine all the year around.

${ }^{5}$ Trade names in this publication are used only to provide specific information. Mention of a trade name does not constitute a warranty of equipment or materials by the Agricultural Experiment Station of the University of Puerto Rico, nor is this mention a statement of preference over other equipment or materials. 
TABLE 2.-Temperature variation at different locations of the engine

\begin{tabular}{|c|c|c|c|c|c|c|c|c|c|c|c|c|}
\hline \multicolumn{12}{|c|}{ Location } & \multirow{2}{*}{ Time (min } \\
\hline 1 & 2 & 3 & 4 & 5 & 6 & 7 & 8 & 9 & 10 & 11 & 12 & \\
\hline \multicolumn{12}{|c|}{ Temperature $-{ }^{\circ} \mathrm{F}$} & \\
\hline 74 & 74. & 74 & 75 & 75 & 75 & 173 & 71 & 71 & 74 & 71 & 74 & 0 \\
\hline 74 & 74 & 74 & 76 & 75 & 75 & 185 & 71 & 71 & 75 & 72 & 75 & 3.3 \\
\hline 74 & 74 & 74 & 78 & 77 & 78 & 300 & 71 & 71 & 76 & 106 & 76 & 6.6 \\
\hline 74 & 75 & 75 & 82 & 78 & 78 & 300 & 71 & 71 & 76 & 120 & 76 & 9.9 \\
\hline 75 & 75 & 75 & 84 & 78 & 80 & 300 & 70 & 72 & 77 & 128 & 77 & 13.2 \\
\hline 74 & 74 & 74 & 87 & 78 & 82 & 300 & 68 & 72 & 77 & 138 & 77 & 16.5 \\
\hline 73 & 73 & 73 & 89 & 78 & 85 & 300 & 67 & 73 & 77 & 149 & 77 & 19.8 \\
\hline 72 & 72 & 72 & 164 & 187 & 171 & 300 & 67 & 73 & 103 & 87 & 77 & 23.1 \\
\hline 170 & 195 & 202 & 196 & 192 & 162 & 300 & 65 & 75 & 113 & 94 & 77 & 26.4 \\
\hline 166 & 196 & 203 & 197 & 193 & 166 & 300 & 66 & 75 & 87 & 97 & 77 & 29.7 \\
\hline
\end{tabular}

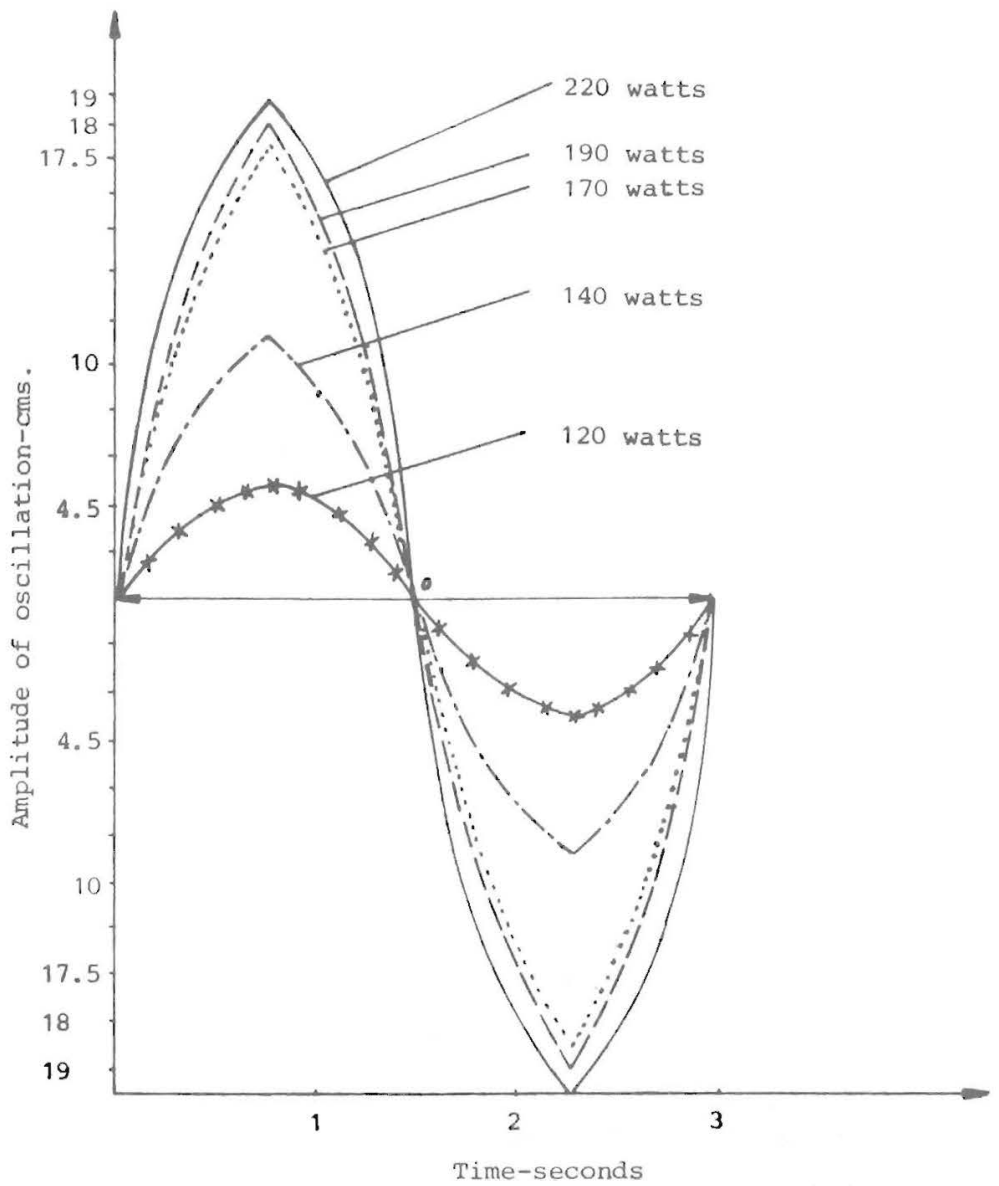

FIG. 4.-Amplitude variation of oscillation for different watts input. 


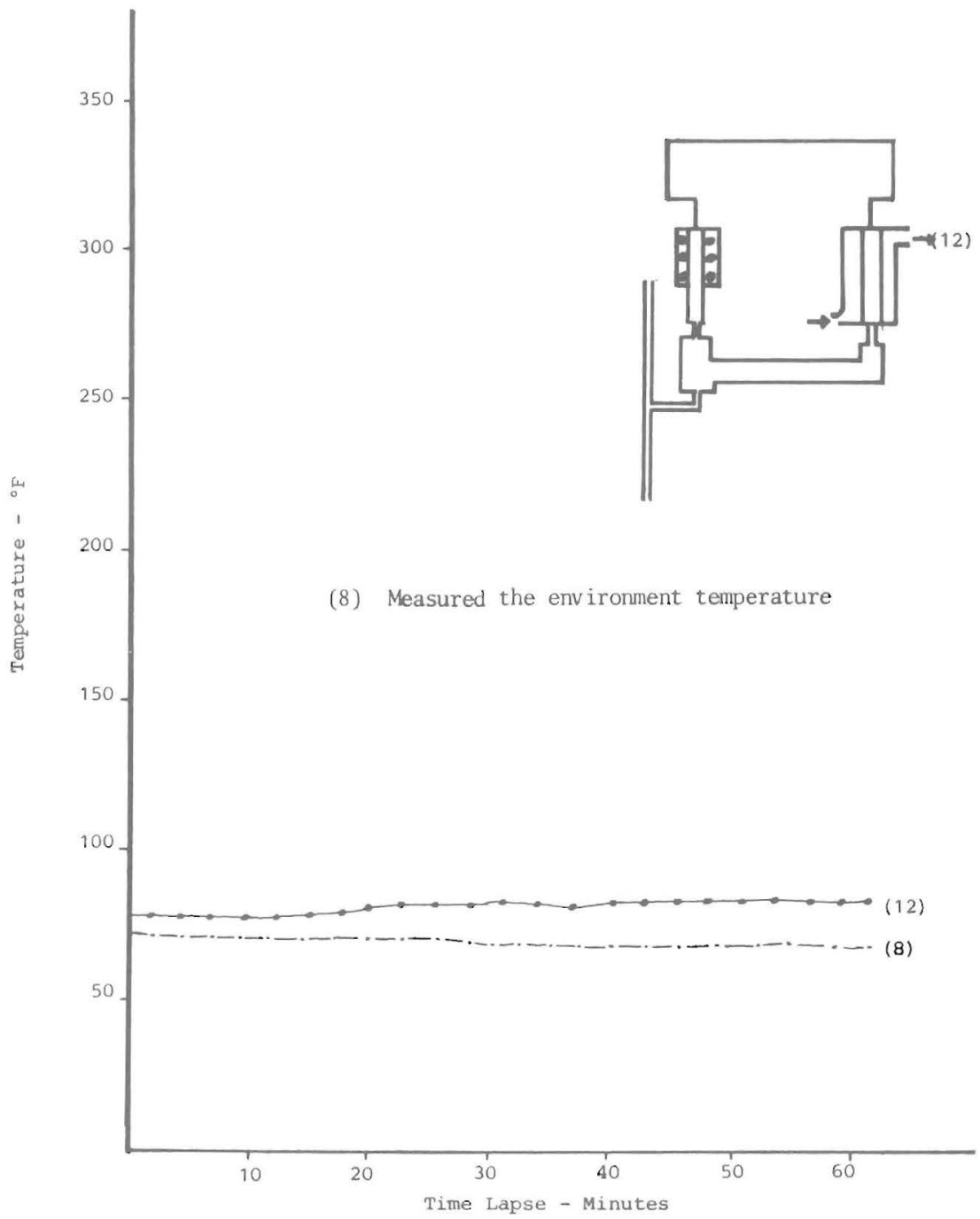

FIG. 5.-Temperature variation with lapsed time of out-coming cooling water and the environment.

Figures 5, 6, and 7 show the temperature variation vs. lapsed time at different locations on the constructed fluidyne engine for 120 watts input.

\section{RESUMEN}

Los principios básicos del motor "stirling" son la piedra angular del concepto del motor "Fluidyne", el cual utiliza fuentes de calor de bajo costo como desperdicios y energía solar que son abundantes en Puerto Rico. 


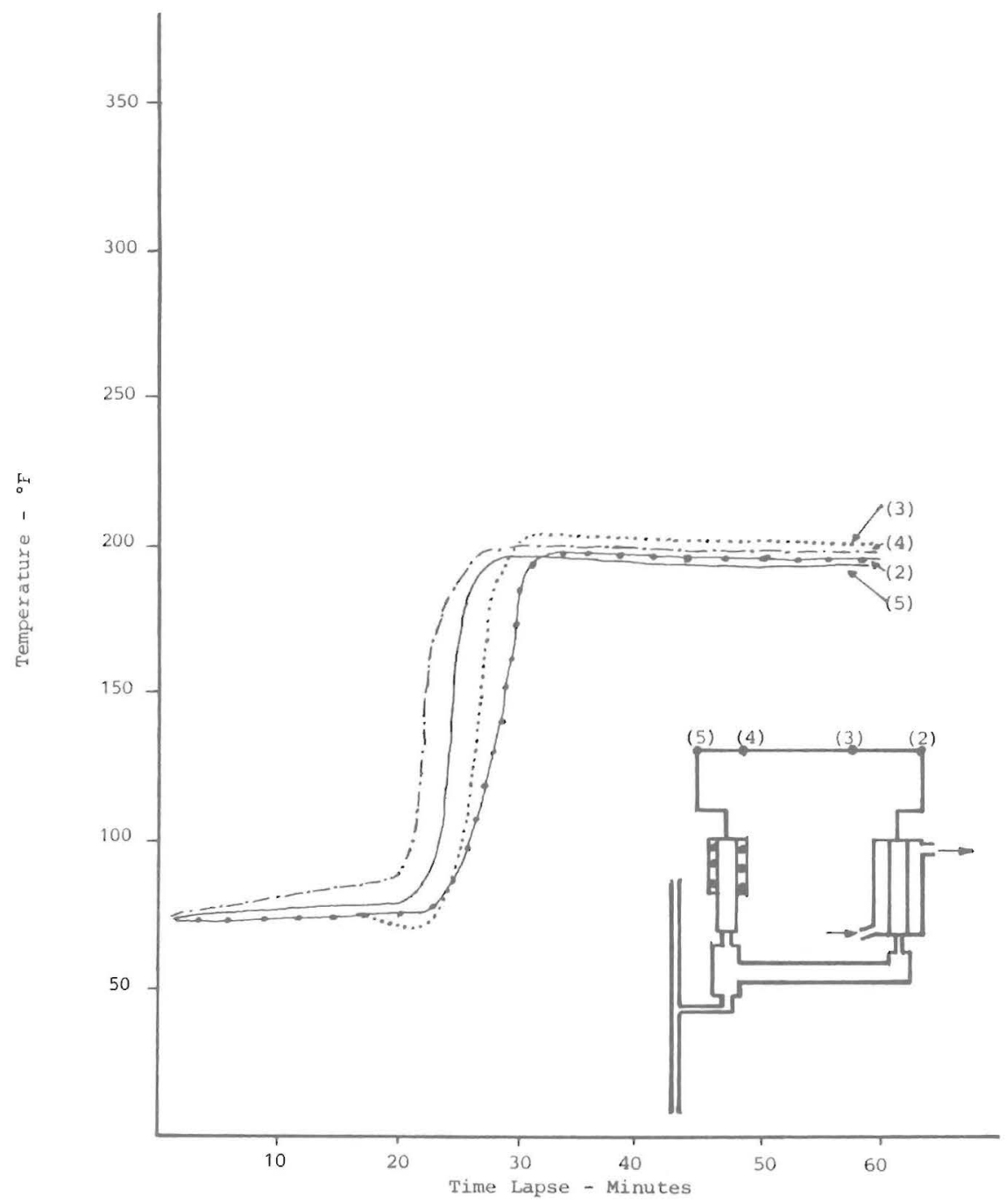

FIG. 6.-Temperature variation at points on generator for 120 watts input in relation to time from the start of heat input.

El motor "Fluidyne" consiste de dos partes básicas, el flotador (displacer) que consta de una parte fría y una caliente hechas de tubo de cobre y una salida que comparte la parte caliente con el flotador. Un regenerador conecta estos tubos de cobre y conduce el aire caliente de la parte fría a la caliente. Dos válvulas de retención, una a cada extremo de los tubos de salida, le permiten funcionar. Diferentes valores de energía a la entrada (vatios) se probaron, y la temperatura en diferentes puntos se registró. 


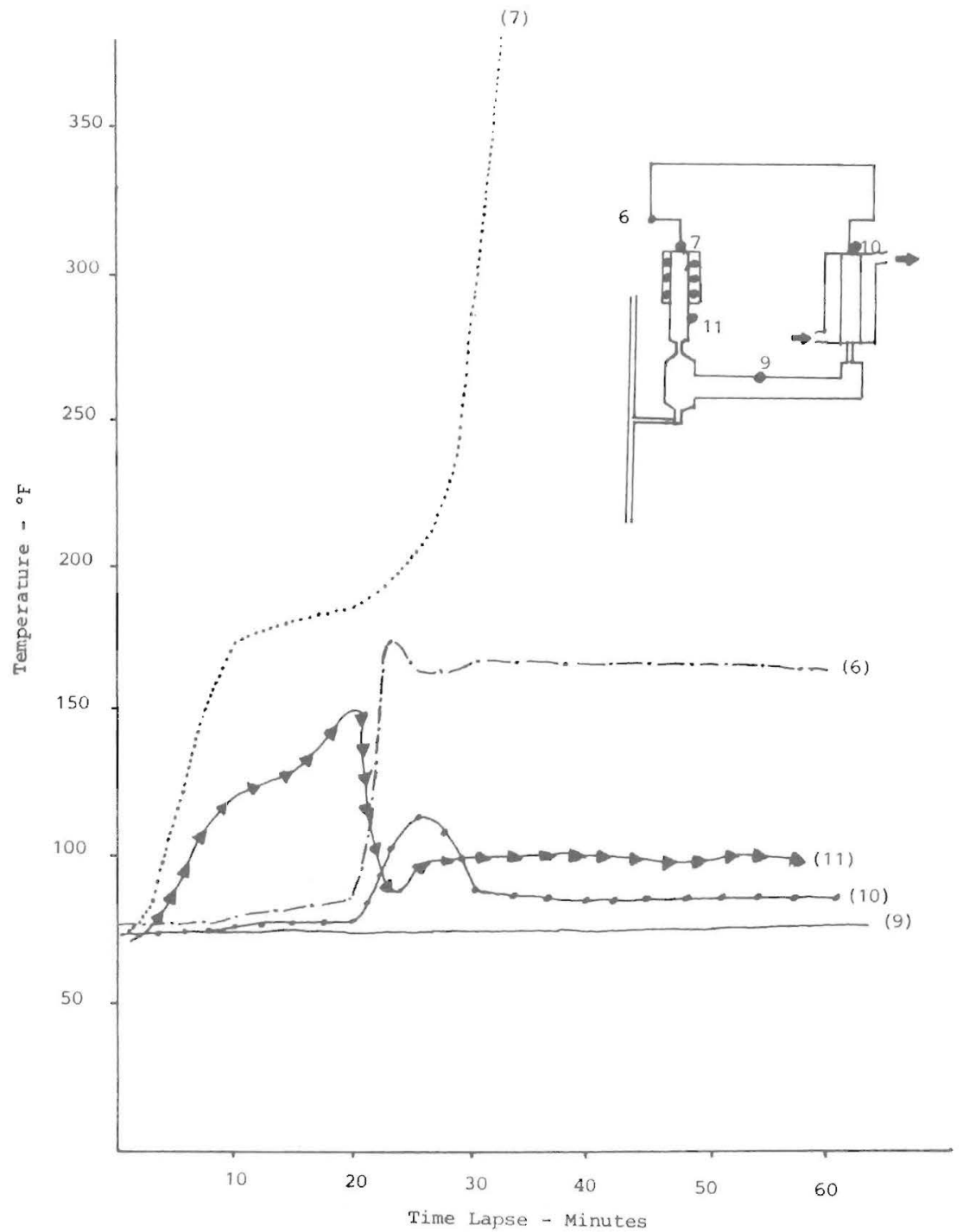

FrG. 7.-Temperature variation V.S. lapsed time at points indicated for 1.20 watts input.

Para que el "Fluidyne" pueda encender por sí solo la diferencia en temperatura entre el lado caliente y el lado frío tiene que llegar a un valor crítico. La temperatura inicial del agua en el motor con tasa de calentamiento fijo de 120 vatios y el flujo de enfriamiento a razón de $600 \mathrm{~cm}^{3}$ / min. de agua con un tubo vertical de salida de $60 \mathrm{~cm}$. de largo fue de $150^{\circ}$ F. El calor calculado para este motor por las condiciones dadas fue de 
55,515 colorías (y la cantidad de calor requerida para cada oscilación a ser creada fue de $124 \mathrm{cal})$. Los ensayos demuestran que el incremento en la entrada de energía no tiene un efecto significativo en los períodos de oscilación, pero sí aumenta su amplitud.

El período de oscilación medido en el motor construido fue de 3 segundos. El tamaño y dimensiones de los tubos, las clases de tubos, la aspereza de su superficie y rozamiento, que disminuyen la capacidad del sistema y la tasa de calentamiento y enfriamiento, fueron los factores que afectaron el rendimiento del motor.

\section{LITERATURE CITED}

1. Committee on Resources and Man, National Academy of Science, National Research Council, 1969. Resources and Man, W. H. Freeman and Company, San Francisco.

2. Farrington, D., 1964, Direct Use of Sun's Energy, Ballantine Books, New York.

3. Gross, B., 1975. The Stirling Engine, Sherman Oaks, California.

4. Sandfort, J. F., 1962. Heat Engines, Anchor Books, Doubleday and Company, Inc., Garden City, New York, pp. 91-129.

5. The Mother Earth News, 1974. Handbook of Homemade Power, Bantam Book, New York.

6. West, C., 1974. And Yet it Moves, New Scientist, pp. 330-1. 